Supporting Information

\title{
Small and bright water-protected upconversion nanoparticles with long-time stability in complex, aqueous media by phospholipid membrane coating
}

Susanne Märkl, Alexandra Schroter and Thomas Hirsch*

University of Regensburg, Institute for Analytical Chemistry, Chemo- and Biosensors, 93040 Regensburg, Germany

Table of Contents

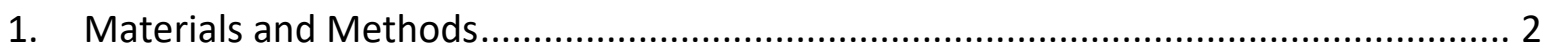

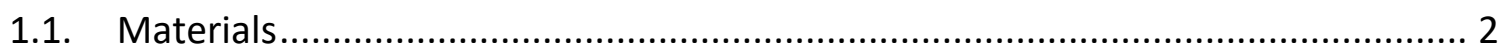

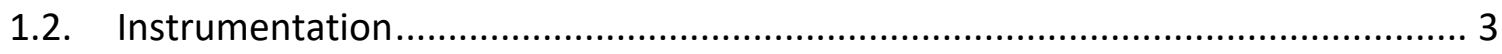

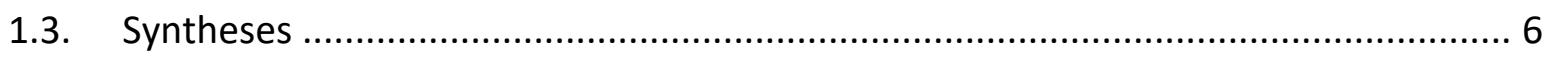

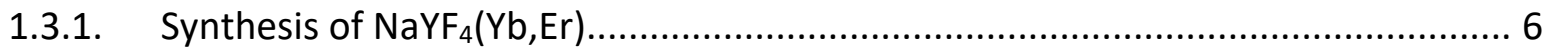

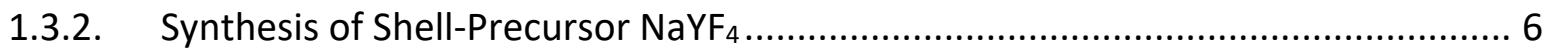

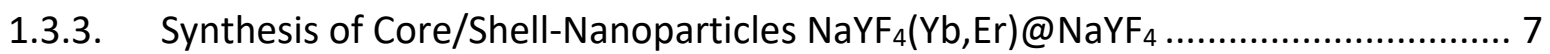

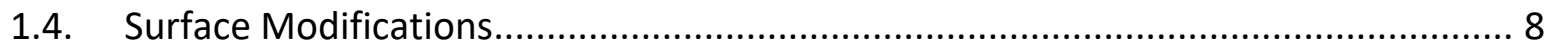

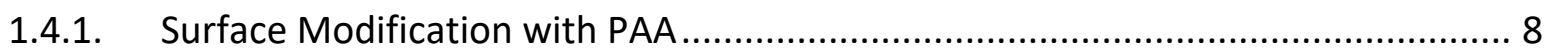

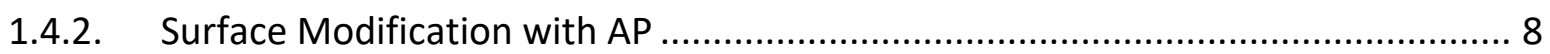

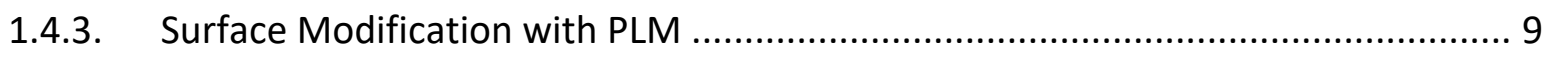

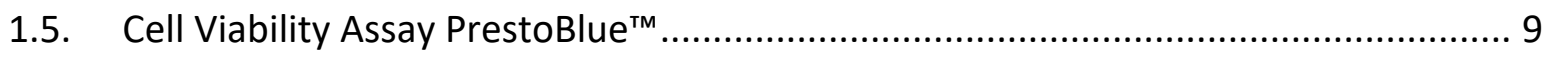

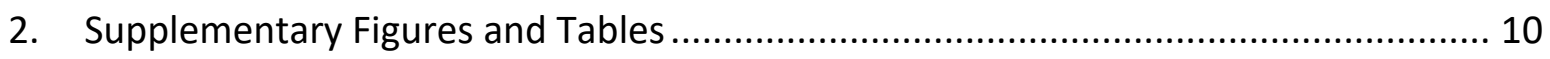

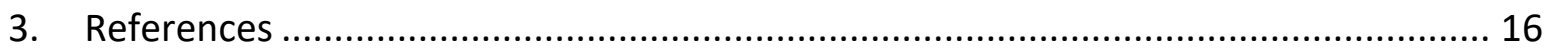




\section{Materials and Methods}

\subsection{Materials}

The chemicals 1-octadecene (90\%) and oleic acid (90\%) were purchased from Alfa Aesar. Chloroform (99.98 \%), DMF (99.9\%) and methanol (99.99\%) were from Fisher Chemical. Hexane (95\%) was bought from Acros. Acetic acid (100\%), sodium acetate (99\%), $\mathrm{Na}_{2} \mathrm{CO}_{3}$ (99.5\%), $\mathrm{NaOH}, \mathrm{Na}_{2} \mathrm{HPO}_{4}$ (99.5\%), $\mathrm{Na}_{2} \mathrm{SO}_{4}$ (99\%), $\mathrm{KCl}$ (99.5\%), $\mathrm{KH}_{2} \mathrm{PO}_{4}$ (99.5\%), was obtained from Merck. Thulium(III) chloride hexahydrate (99.99\%), NOBF 4 (95\%), poly(acrylic acid) (2,100 kDa), phosphotungstic acid PTA (99.995\%), $\mathrm{MgCl}_{2}$ (98\%), poly(isobutylene-alt-maleic anhydride $(6,000 \mathrm{kDa})$, dodecylamine (98\%), Dulbecco's phosphate buffered saline (PBS), Dulbecco's Modified Eagle's Medium (DMEM) - high glucose, D-glucose, L-glutamine, 2-[4-(2hydroxyethyl)piperazine-1-ethanesulfonic acid (HEPES, 99.5\%), cholesterol (99\%), penicillin, streptomycin and fetal calf serum (FCS) were purchased from Sigma Aldrich. Ytterbium(III) chloride hexahydrate (99.999\%) and yttrium(III) chloride hexahydrate $(99.99 \%)$ were obtained from Treibacher Industrie AG. Cyclohexane (100\%) and $\mathrm{NaCl}$ was from VWR Chemicals. 1,2Dioleoyl-sn-glycero-3-phosphate (sodium salt) (DOPA) and 1,2-dioleoyl-sn-glycero-3phosphoethanolamine (DOPE) were bought from Avanti Polar Lipids. $\mathrm{CaCl}_{2}$ (94\%) was from Carl Roth and $\mathrm{NaHCO}_{3}(99.5 \%)$ from Ferak. Multi element standard (pure plus) were obtained from PerkinElmer. Leibovitz medium L15 was obtained from Life Technology. Normal rat kidney epithelial cells of the cell line NRK-52E were obtained from Deutsche Sammlung von Mikroorganismen und Zellkulturen. All chemicals were used as received without any further purification. All aqueous solutions were prepared with double distilled water. 


\subsection{Instrumentation}

The composition of the UCNPs and their mass concentrations were determined by optical emission spectroscopy combined with inductive coupled plasma excitation (ICP-OES) Spectroblue FMX36 from Spectro. Calibrations were performed using a multielement standard from PerkinElmer. The UCNPs were dried, dissolved in sulfuric acid (150 $\mu \mathrm{L}, \geq 95 \%, \mathrm{w} / \mathrm{w})$ and diluted with double distilled water $(5.85 \mathrm{~mL})$.

Luminescence spectra were recorded with a home-built set-up. The spectrometer (225$1000 \mathrm{~nm}$ ) and the Software Waves were obtained from former RGB photonics, now Broadcom. Mounts, filters, lenses, fibers were bought from Thorlabs and Spindler and Hoyer, now Qioptiq. Optical fibers were from Thorlabs and Ocean Optics. The 980 nm, $200 \mathrm{~mW} \mathrm{cw}$ laser was obtained from Picotronic and equipped with an adjustable stage from Mitutoyo and Edmund Optics for a precise control of $x-, y$ - and z-direction. Measurements in aqueous media were performed at $144 \mathrm{~W} \cdot \mathrm{cm}^{-2}$ resulting in $85 \mathrm{~W} \cdot \mathrm{cm}^{-2}$ due to water absorption in a $1 \mathrm{~cm}$ light path. The laser power density was adjusted to $85 \mathrm{~W} \cdot \mathrm{cm}^{-2}$ with NOD filters for comparable measurements in cyclohexane and heavy water. As the detector is not calibrated, the equally recorded luminescence spectra in this paper can be only compared among each other and not to the spectra in other papers.

Dynamic light scattering measurements of the Particles $\left(1 \mathrm{mg} \cdot \mathrm{mL}^{-1}\right.$ and $0.2 \mathrm{mg} \cdot \mathrm{mL}^{-1}$ respectively) were performed with the Malvern Zetasizer Nano ZS. The mean solvodynamic diameter with the corresponding error as standard deviations SD from three measurements is determined.

The surface zeta potential of the UCNPs@PLM $\left(0.2 \mathrm{mg} \cdot \mathrm{mL}^{-1}\right)$ in various ion solutions and buffers was determined with the Malvern Zetasizer Nano ZS. The mean zeta potential with the corresponding error as standard deviations SD from three measurements is determined. The conductivity was always between 0.2 and $5 \mathrm{~ms} \cdot \mathrm{cm}^{-1}$, except for the $138 \mathrm{mM} \mathrm{NaCl}$ solution. Here the conductivity was $>5 \mathrm{~ms} \cdot \mathrm{cm}^{-1}$ and the obtained result for the UCNPs in the $\mathrm{NaCl}$ solution must be treated with caution. 
Transmission electron microscopy (TEM) was performed with the $120 \mathrm{kV}$ CM12 microscope from Phillips. The particle dispersions $\left(\approx 1.5 \mathrm{mg} \cdot \mathrm{mL}^{-1}\right.$ in $\mathrm{C}_{6} \mathrm{H}_{12}$ or double distilled $\mathrm{H}_{2} \mathrm{O}$ ) were dropped on copper grids (coated with carbon, 400 mesh) from Plano. The samples for the negative staining were prepared as follows: The carbon coated copper grids were made hydrophilic with $15 \mathrm{sscm} \mathrm{O}_{2}$ for $1 \mathrm{~min}$ by the PlasmaFlecto 10 from Plasma Technology. After the particle dispersion $\left(\approx 1.5 \mathrm{mg} \cdot \mathrm{mL}^{-1} \mathrm{dd} \mathrm{H}_{2} \mathrm{O}\right)$ was dropped on the hydrophilized grid and blotted out with a filter paper, the UCNPs@PLM were negatively stained with a PTA solution $(1 \% \mathrm{w} / \mathrm{v}, \mathrm{pH} 7.25)$ for $90 \mathrm{~s}$. The excess solution was again removed with a filter paper. All obtained micrographs were evaluated with the software ImageJ.

X-Ray diffraction patterns (XRD) of the UCNPs were determined by a STOE STADI P diffractometer with a Dectris Mythen $1 \mathrm{~K}$ detector using monochromatic $\mathrm{Cu}_{\mathrm{K} \alpha}$ radiation $(\lambda=1.54056 \AA)$ and a step size of $0.005^{\circ}$.

Thermogravimetric analysis of OA coated UCNPs was carried out under $\mathrm{N}_{2}$ with a Mettler Toledo TG 50 from $25-700{ }^{\circ} \mathrm{C}$ with a heating rate of $10{ }^{\circ} \mathrm{C} / \mathrm{min}$. A rough estimation of the surface coverage of the UCNPs $\mathrm{NaYF}_{4}(\mathrm{Yb}, \mathrm{Er}) @ \mathrm{NaYF}_{4}$ with OA can be determined by the following equations.

The relative mass loss is assumed to be only due to surface ligands, thus the absolute mass is the sum of the mass of plain UCNPs and the mass of OA ligands:

$$
m_{\text {total }}=m_{\text {plain UCNPs }}+m_{O A}
$$

The number of UCNPs can be determined from the mass of plain UCNPs and the mass of one single UCNP:

$$
N_{U C N P S}=\frac{m_{\text {plain UCNPS }}}{m_{U C N P}}
$$

The mass of one UCNP can be calculated by the density of $\mathrm{NaYF}_{4}(4.23)^{[1]}$ and the volume of one UCNP, which is obtained from TEM analysis ( $d=12 \mathrm{~nm}$, Figure $\mathbf{X}$ ) and the hexagonal geometry of the UCNPs with $2 \cdot a=h=d=12 \mathrm{~nm}$. 


$$
m_{U C N P}=\frac{\rho_{N a Y F_{4}}}{V_{U C N P}}=\frac{\rho_{N a Y F_{4}}}{6 \cdot a^{2} \cdot \frac{\sqrt{3}}{4} \cdot h}=\frac{\rho_{N_{a Y F_{4}}}}{\frac{3 \sqrt{3}}{8} \cdot d^{3}}
$$

As the number of total $\mathrm{OA}$ molecules is $N_{O A}=\frac{m_{O A}}{M_{O A}} \cdot N_{A}$, the amount of OA ligands per one single particle is obtained by

$$
N_{O A / U C N P}=\frac{N_{O A}}{N_{U C N P S}}
$$

By calculating the surface area of one $12 \mathrm{~nm}$ hexagonal UCNPs $\left(A_{U C N P}=6 \cdot a \cdot h+3 \sqrt{3} \cdot a^{2}\right)$ and taking into account the surface of the carboxylic group of $\mathrm{OA}\left(0.2 \mathrm{~nm}^{2}\right)^{[2,3]}$ a total surface coverage of $77 \%$ by OA ligands is obtained. 


\subsection{Syntheses}

\subsubsection{Synthesis of $\mathrm{NaYF}_{4}(\mathrm{Yb}, \mathrm{Er})$}

Hexagonal upconversion nanoparticles $\beta-\mathrm{NaYF}_{4}(\mathrm{Yb}, \mathrm{Er})$ were synthesized in high boiling solvents oleic acid and octadecene (1:1) using a high sodium oleate to rare earth oleate ratio according to a protocol by Haase et al. ${ }^{[4]}$ Briefly, rare earth (RE) oleates (OA) were prepared by dissolving the $\mathrm{RE}$ chlorides $\mathrm{YCl}_{3} \cdot \mathrm{H}_{2} \mathrm{O}(23.4 \mathrm{mmol}), \mathrm{YbCl}_{3} \cdot \mathrm{H}_{2} \mathrm{O}(6 \mathrm{mmol})$ and $\mathrm{ErCl}_{3} \cdot \mathrm{H}_{2} \mathrm{O}$ $(0.6 \mathrm{mmol})$ in $\mathrm{H}_{2} \mathrm{O}(39 \mathrm{~mL})$. EtOH $(60 \mathrm{~mL})$ and hexane $(105 \mathrm{~mL})$ were added to dissolve sodium oleate $\left(30 \mathrm{mmol}\right.$ ). After refluxing at $\approx 60^{\circ} \mathrm{C}$ overnight, the reaction mixture was cooled to room temperature. The upper phase was evaporated in vacuum to obtain a waxy product. RE-OA $(10 \mathrm{mmol})$ and sodium oleate $(80 \mathrm{mmol})$ were dissolved in oleic acid $(120 \mathrm{~mL})$ and octadecene $(120 \mathrm{~mL})$. After heating the reaction mixture to $100{ }^{\circ} \mathrm{C}$ under nitrogen followed by an evaporation for $1 \mathrm{~h}$ a clear solution was obtained. $\mathrm{NH}_{4} \mathrm{~F}(110 \mathrm{mmol})$ was added under nitrogen and the mixture was degassed three times. It was heated to $300-325^{\circ} \mathrm{C}\left(16^{\circ} \mathrm{C} \cdot \mathrm{min}^{-1}\right)$ for $30 \mathrm{~min}$ before it was cooled to room temperature. The suspension was centrifuged $(1,000 \mathrm{~g}$, $3 \mathrm{~min})$, the obtained pellet was washed with cyclohexane and centrifuged again. The nanoparticles precipitate from the supernatant by adding ethanol $(\approx 1: 5, \mathrm{v} / \mathrm{v})$ and get collected by centrifugation (3000 g, $5 \mathrm{~min})$. Two washing steps were performed with cyclohexane/ethanol $(\approx 1: 10, v / v)$ and finally, the pure hexagonal nanoparticles were redispersed in cyclohexane.

\subsubsection{Synthesis of Shell-Precursor $\mathrm{NaYF}_{4}$}

Y-OA was prepared analogous to the RE OA protocol. Yttrium oleate $(20 \mathrm{mmol})$ and sodium oleate $(40 \mathrm{mmol})$ were dissolved in oleic acid $(200 \mathrm{~mL})$ and octadecene $(200 \mathrm{~mL})$ and heated under nitrogen atmosphere to $100{ }^{\circ} \mathrm{C}$. The reaction mixture was degassed under vacuum for $1 \mathrm{~h}$ at $100^{\circ} \mathrm{C}$ and after the addition of $\mathrm{NH}_{4} \mathrm{~F}(100 \mathrm{mmol})$ it was heated to $200^{\circ} \mathrm{C}$ for $1 \mathrm{~h}$. Cooled to room temperature, the nanoparticles were precipitated with ethanol $(\approx 1: 5, v / v)$ and collected by centrifugation $(3,000 \mathrm{~g}, 5 \mathrm{~min})$. After two washing steps with cyclohexane/ethanol $(\approx 1: 10 \mathrm{v} / \mathrm{v})$, the pure shell material $\alpha-\mathrm{NaYF}_{4}$ was dispersed in cyclohexane. 


\subsubsection{Synthesis of Core/Shell-Nanoparticles $\mathrm{NaYF}_{4}(\mathrm{Yb}, \mathrm{Er}) @ \mathrm{NaYF}_{4}$}

Hexagonal core-shell nanoparticles $\mathrm{NaYF}_{4}(\mathrm{Yb}, \mathrm{Er}) @ \mathrm{NaYF}_{4}$ with $1 \mathrm{~nm}$ thick shell were synthesized using $\beta-\mathrm{NaYF}_{4}(\mathrm{Yb}, \mathrm{Er})$ and $\alpha-\mathrm{NaYF}_{4}$ in a ratio of 5:4. $\beta-\mathrm{NaYF}_{4}(\mathrm{Yb}, \mathrm{Er})(2-\mathrm{mmol})$ and $\alpha-\mathrm{NaYF}_{4}(0.5-\mathrm{mmol})$ were dissolved separately in 1-octadecene $(10-\mathrm{mL})$ and oleic acid $(10 \mathrm{~mL})$. Both solutions were heated to $125^{\circ} \mathrm{C}$ under nitrogen, followed by evaporation at $125^{\circ} \mathrm{C}$ for $15 \mathrm{~min}$. Whereas the $\beta$-UCNPs were combined with $2 \mathrm{~mL}$ of shell precursor material under nitrogen and heated to $325{ }^{\circ} \mathrm{C}\left(16{ }^{\circ} \mathrm{C} \cdot \mathrm{min}^{-1}\right)$, the residual $\alpha$-UCNPs were kept at $125^{\circ} \mathrm{C} \cdot \alpha-$ UCNPs were injected in small portions every $5 \mathrm{~min}$. After the final addition the solution was refluxed for $5 \mathrm{~min}$ before cooling to room temperature. The purification of the core-shellUCNPs was done in the same way as described in the synthesis of $\beta-\mathrm{NaYF}_{4}(\mathrm{Yb}, \mathrm{Er})$.

$\mathrm{NaYF}_{4}(\mathrm{Yb}, \mathrm{Tm})$ and $\mathrm{NaYF}_{4}(\mathrm{Yb}, \mathrm{Tm}) @ \mathrm{NaYF}_{4}$ were prepared analogously with the RE chlorides $\mathrm{YCl}_{3} \cdot \mathrm{H}_{2} \mathrm{O}(22.41 \mathrm{mmol}), \mathrm{YbCl}_{3} \cdot \mathrm{H}_{2} \mathrm{O}(7.5 \mathrm{mmol})$ and $\mathrm{TmCl}_{3} \cdot \mathrm{H}_{2} \mathrm{O}(0.09 \mathrm{mmol})$. 


\subsection{Surface Modifications}

\subsubsection{Surface Modification with PAA}

The UCNPs were modified with PAA in a two-step process using nitrosyl tetrafluoroborate..$^{[5]}$ At first, DMF (3 mL) and oleate-coated UCNPs NaYF4:Yb,Er@NaYF $(200 \mathrm{mg}$ in $3 \mathrm{~mL}$ cyclohexane) were mixed and stirred at $30^{\circ} \mathrm{C}$. After $10 \mathrm{~min} \mathrm{NOBF}_{4}$ was added in excess $(500 \mathrm{mg}$ ) and stirred for another $20 \mathrm{~min}$. The oleate-free particles in the DMF phase were precipitated by the addition of $\mathrm{CHCl}_{3}(\approx 1: 10, \mathrm{v} / \mathrm{v})$ and collected via centrifugation $(1,000 \mathrm{~g}$, $5 \mathrm{~min}$ ). The nanoparticles were washed by dispersing in DMF and precipitating with $\mathrm{CHCl}_{3}$. After centrifugation (1,000 g, $5 \mathrm{~min}$ ) the $\mathrm{BF}_{4}{ }^{-}$stabilized UCNPs are finally dispersed in DMF and aggregates were removed by centrifugation $(1,000 \mathrm{~g}, 5 \mathrm{~min})$.

The $\mathrm{BF}_{4}{ }^{-}$was substituted with the ligand PAA. Thus, poly(acrylic acid) (20 mg, $\mathrm{M}_{\mathrm{W}} \approx 2,100 \mathrm{kDa}$ ) was dissolved in $10 \mathrm{~mL}$ 4-(2-hydroxyethyl)-1-piperazineethanesulfonic acid (HEPES, $10 \mathrm{mM}$, $\mathrm{pH} \mathrm{7.4)}$ and stirred at room temperature for $10 \mathrm{~min}$. $\mathrm{BF}_{4}{ }^{-}$-stabilized UCNPs (100 mg in $2.5 \mathrm{~mL}$ DMF) were slowly added and the clear mixture was stirred at room temperature for $20 \mathrm{~min}$. The UCNPs were collected by repeated centrifugation steps $(21,000 \mathrm{~g}$, at least $2 \mathrm{~h})$ until the supernatant did not show any upconversion luminescence upon irradiation with a 980-nm laser module $(200 \mathrm{~mW}, \mathrm{cw})$. The UCNPs pellet was purified twice by dispersing in double distilled water or HEPES, followed by centrifugation $(21,000 \mathrm{~g}, 2 \mathrm{~h})$. Finally, the UCNPs were dispersed in water or HEPES and aggregates were removed (1,000 g, $5 \mathrm{~min})$. The PAA modified particles are stored in the fridge.

\subsubsection{Surface Modification with AP}

The UCNPs were coated with an amphiphilic polymer (AP) to form a bilayer with oleate as inner leaflet. ${ }^{[6]}$ Firstly, the oleate capped UCNPs NaYF4:Yb,Er@NaYF $(200 \mathrm{mg})$ were dried and dispersed in $\mathrm{CHCl}_{3}(3 \mathrm{~mL})$. Then the amphiphilic polymer poly(isobutyl-maleic anhydride) with $75 \%$ dodecylamine side chains (PIBMAD) with 75\% dodecylamine side chains (16 mL $0.5 \mathrm{M}$ in $\mathrm{CHCl}_{3}$ ) was added. The dispersion was stirred at room temperature for $30 \mathrm{~min}$ and the solvent was removed under vacuum. The polymer was dispersed in $\mathrm{NaOH}(0.2 \mathrm{M}, 20 \mathrm{~mL})$ and sonicated for $30 \mathrm{~min}$. The UCNPs were washed as described in 1.4.1 and dispersed in double distilled water or HEPES. 


\subsubsection{Surface Modification with PLM}

The UCNPs were equipped with a phospholipid mixture to form together with the oleate already attached to the particle a bilayer. Thus, oleate coated UCNPs NaYF $4: Y b, E r @ N a Y F_{4}$ $\left(2 \mathrm{mg}\right.$ ) dissolved in cyclohexane were dried and dispersed in $\mathrm{CHCl}_{3}(1.5 \mathrm{~mL})$. The lipid mixture (29 $\mu \mathrm{mol}$, e.g. 64\% DOPA, 7\% DOPE, 29\% cholesterol, in $1.5 \mathrm{~mL} \mathrm{CHCl} 3$ ) was added and the clear solution was sonicated for $10 \mathrm{~min}$. Afterwards the solution was kept under vacuum for a few minutes to obtain a nanoparticle-lipid film. The film was dispersed in $\mathrm{CHCl}_{3}(1.5 \mathrm{~mL})$, sonicated and evaporated two more times. After the final evaporating step, the lipid film was further dried under vacuum for $12 \mathrm{~h}$ to remove residual solvent traces. The film was hydrated in $15 \mathrm{mM} \mathrm{NaCl}$ solution or in HEPES buffer $(10 \mathrm{mM}, \mathrm{pH} 7.4)$ under rigorous stirring at $70^{\circ} \mathrm{C}$ for $1 \mathrm{~h}$ and sonicated for $20 \mathrm{~min}$. Lipid modified UCNPs were collected by centrifugation $(3,000 \mathrm{~g}$, $5 \mathrm{~min}$ ). The modified UCNPs were extruded 19-times through a $100 \mathrm{~nm}$ membrane at $70^{\circ} \mathrm{C}$ and centrifuged $(21,000 \mathrm{~g}, 2 \mathrm{~h})$. The pellet was dispersed in double distilled water $(500 \mu \mathrm{L})$ and was centrifuged again $(21,000 \mathrm{~g}, 2 \mathrm{~h})$. After dispersing in water or HEPES (500 $\mu \mathrm{L})$ aggregates were removed by centrifugation $(1,000 \mathrm{~g}, 3 \mathrm{~min})$ and stored at $6^{\circ} \mathrm{C}$.

\subsection{Cell Viability Assay PrestoBlue ${ }^{\mathrm{TM}}$}

Normal rat kidney (NRK) cells were seeded on 96 well plates in DMEM (3.7 $\mathrm{g} \mathrm{NaHCO}_{3}, 4.5 \mathrm{~g} \cdot \mathrm{L}^{-1}$ D-glucose, $5 \%(\mathrm{v} / \mathrm{v}) \mathrm{FCS}, 1 \mathrm{mM} \mathrm{L}$-glutamine, $100 \mu \mathrm{g} \cdot \mathrm{mL}^{-1}$ penicillin and $100 \mu \mathrm{g} \cdot \mathrm{mL}^{-1}$ streptomycin) and allowed to grow to confluence for one week. The cell medium was exchanged after three days and after six days. On day seven, the culture medium was aspirated and $100 \mu \mathrm{L}$ of PLM coated UNCPs were added to the wells in different concentrations $\left(0.5-200 \mu \mathrm{g} \cdot \mathrm{mL}^{-1}\right.$ in L-15 medium with $5 \% \mathrm{FCS}$ and $\left.100 \mu \mathrm{g} \cdot \mathrm{mL}^{-1}\right)$. After the incubation of the NRK cells with the UCNPs at $37^{\circ} \mathrm{C}$ and $0 \% \mathrm{CO}_{2}$ for $24 \mathrm{~h}$ the particle solutions were exchanged with $100 \mu \mathrm{L}$ of the PrestoBlue ${ }^{\mathrm{TM}}$ solution $\left(1: 10, \mathrm{v} / \mathrm{v}\right.$ in PBS $^{++}$containing $1 \mathrm{mg} \cdot \mathrm{mL}^{-1}$ glucose) at $37^{\circ} \mathrm{C}$ and $0 \% \mathrm{CO}_{2}$ for $60 \mathrm{~min}$. Finally, the fluorescence intensity was measured at $\lambda_{\mathrm{em}}=600 \mathrm{~nm}\left(\lambda_{\mathrm{exc}}=532 \mathrm{~nm}\right)$. The PrestoBlue ${ }^{\circledR}$ assay was performed three individual times each with a three-fold determination for every condition. The weighted mean of the cell viability with the corresponding error was calculated. 
2. Supplementary Figures and Tables

Table S1. Composition of $\mathrm{Er}^{3+}$ and $\mathrm{Tm}^{3+}$ doped core and core-shell UNCPs in mole percentage determined by ICP$\mathrm{OES}$ (mean $\pm \mathrm{SD}, \mathrm{N}=3$ ).

\begin{tabular}{ccccc}
\hline & $\boldsymbol{x}\left(\mathrm{Y}^{3+}\right) / \%$ & $\boldsymbol{x}\left(\mathrm{Yb}^{3+}\right) / \%$ & $\boldsymbol{x}\left(\mathrm{Er}^{3+}\right) / \%$ & $\boldsymbol{x}\left(\mathrm{Tm}^{3+}\right) / \%$ \\
\hline $\mathrm{NaYF}_{4}(\mathrm{Yb}, \mathrm{Er})$ & $76.2 \pm 0.2$ & $21.6 \pm 0.3$ & $2.34 \pm 004$ & - \\
$\mathrm{NaYF}_{4}(\mathrm{Yb}, \mathrm{Er}) @ \mathrm{NaYF}_{4}$ & $79.5 \pm 0.5$ & $18.6 \pm 0.1$ & $1.92 \pm 0.01$ & - \\
$\mathrm{NaYF}_{4}(\mathrm{Yb}, \mathrm{Tm})$ & $75.8 \pm 0.5$ & $23.7 \pm 0.2$ & - & $0.576 \pm 0.001$ \\
$\mathrm{NaYF}_{4}(\mathrm{Yb}, \mathrm{Tm}) @ \mathrm{NaYF}_{4}$ & $88.7 \pm 0.6$ & $10.94 \pm 0.04$ & - & $0.359 \pm 0.001$ \\
\hline
\end{tabular}

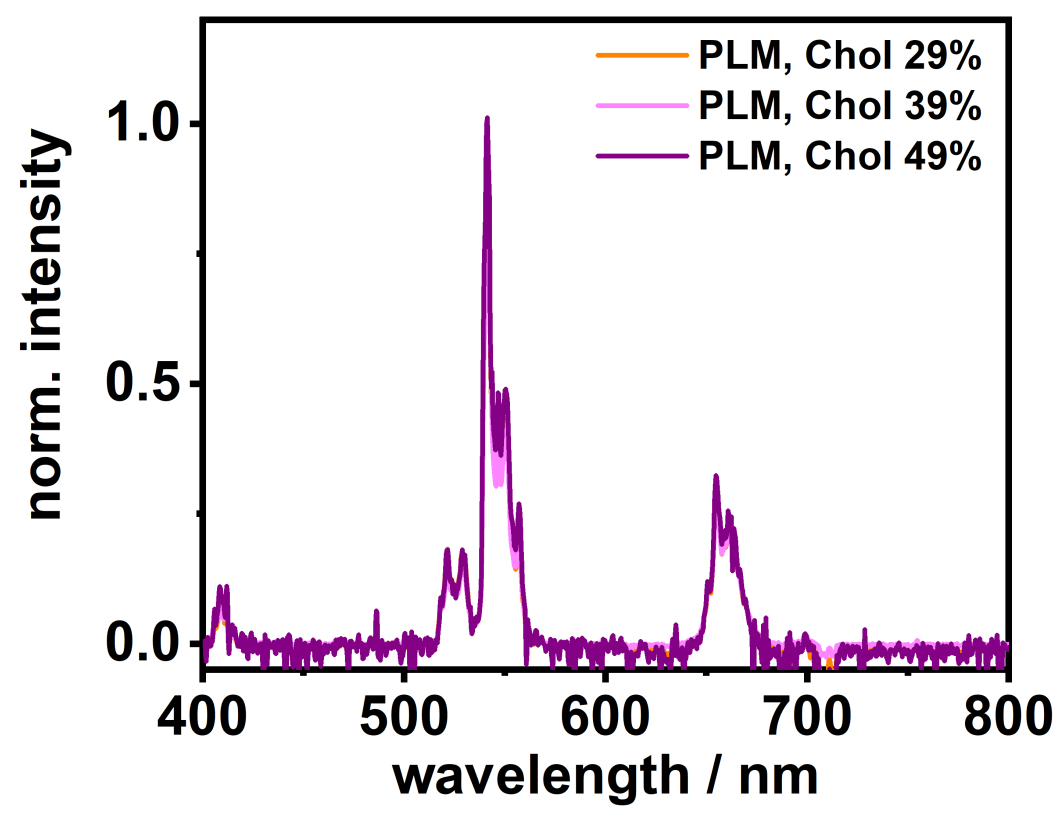

Figure S1. Luminescence spectra of PLM coated UCNPs prepared with a lipid mixture containing $29 \%, 39 \%$ or $49 \%$ in $\mathrm{H}_{2} \mathrm{O}$ upon irradiation with $980 \mathrm{~nm}$ at $\sim 85 \mathrm{~W} \cdot \mathrm{cm}^{-2}\left(1 \mathrm{mg} \cdot \mathrm{mL}^{-1}\right.$, normalized to $\left.\mathrm{N}_{U C N P s}\right)$. 

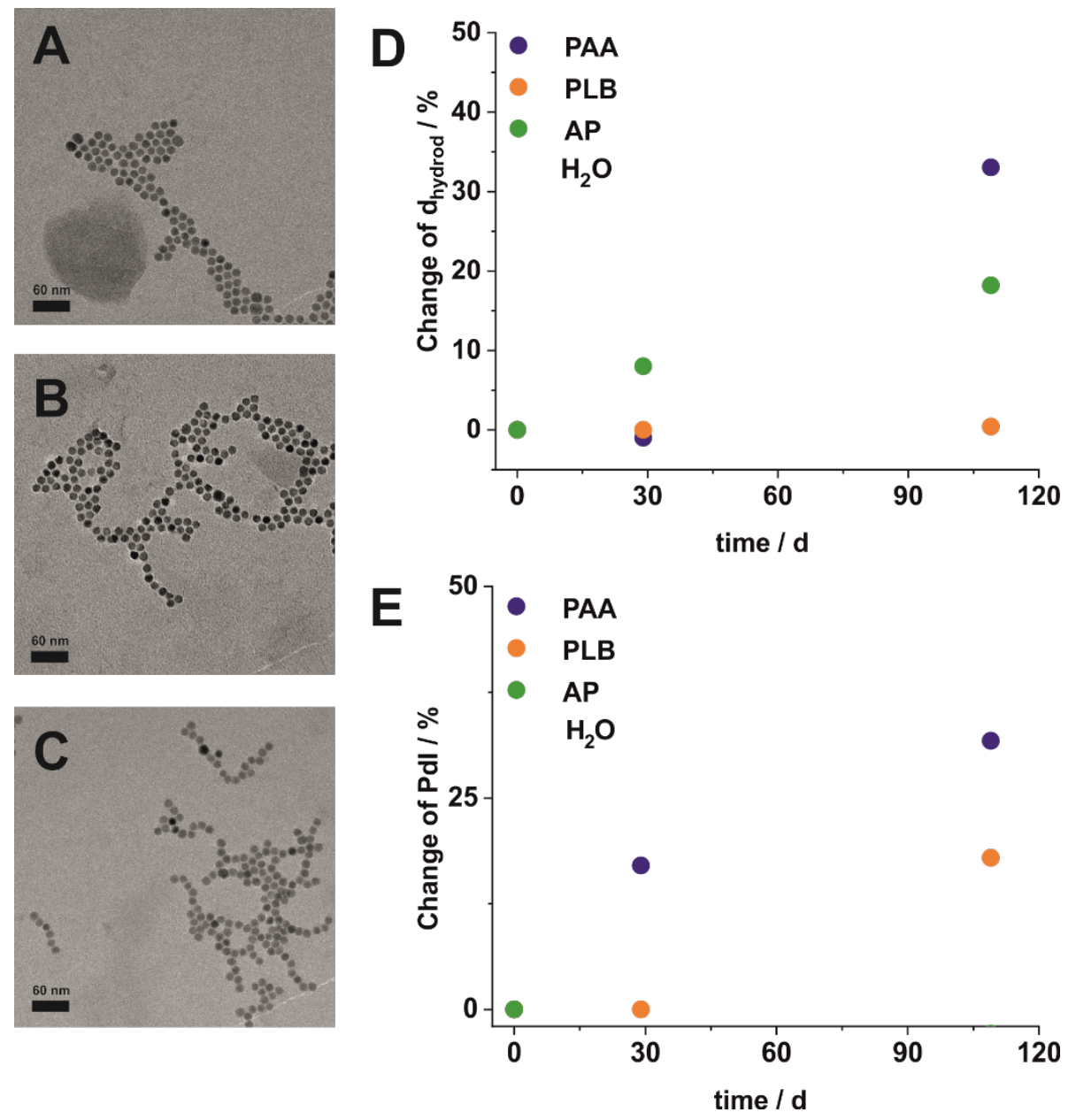

Figure S2. TEM images of surface modified $\mathrm{NaYF}_{4}(\mathrm{Yb}, \mathrm{Er}) @ \mathrm{NaYF}_{4}$ with phospholipid bilayer (PLB), poly(aycrylic acid) (PAA) and amphiphilic polymer (AP) and time dependent change of hydrodynamic diameter and Pdl of PAA, PLM and AP coated UCNPs NaYF $@ N_{4} \mathrm{NFF}_{4}(\mathrm{Yb}, \mathrm{Er})$ in water.

Table S2. Solvodynamic diameter $d_{\text {solv }}$ with corresponding Pdl and zeta potential $\zeta$ of OA and surface modified $\mathrm{UCNPs}^{\mathrm{Er}} \mathrm{NaYF}_{4}(\mathrm{Yb}, \mathrm{Er}) @ \mathrm{NaYF}_{4}$ and $\mathrm{UCNPs}^{\mathrm{Tm}} \mathrm{NaYF}_{4}(\mathrm{Yb}, \mathrm{Tm}) @ \mathrm{NaYF}_{4}$ with phospholipid bilayer (PLM), poly(aycrylic acid) (PAA) and amphiphilic polymer AP.

\begin{tabular}{cccc}
\hline particle system & $\mathbf{d}_{\text {solv }} / \mathbf{n m}$ & Pdl $\pm \mathbf{S D}$ & $\zeta / \mathbf{m V}$ \\
\hline UCNPs $^{\mathrm{Er}} @ \mathrm{OA}$ & $16.15 \pm 0.08$ & $0.10 \pm 0.02$ & - \\
UCNPs $^{\mathrm{Er}} @ \mathrm{PLM}$ & $100 \pm 1$ & $0.11 \pm 0.02$ & $-36.9 \pm 0.3$ \\
UCNPs $^{\mathrm{Er}} @ \mathrm{PAA}$ & $73.1 \pm 0.5$ & $0.184 \pm 0.005$ & $-37 \pm 1$ \\
UCNPs $^{\mathrm{Er}} @ \mathrm{AP}$ & $17.34 \pm 0.04$ & $0.221 \pm 0.002$ & $-39 \pm 1$ \\
UCNPs $^{\top \mathrm{m}} @ \mathrm{OA}$ & $14.1 \pm 0.3$ & $0.11 \pm 0.05$ & - \\
UCNPs $^{\top \mathrm{Tm} @ P L M}$ & $101.2 \pm 0.2$ & $0.19 \pm 0.01$ & - \\
UCNPs $^{\top \mathrm{Tm} @ P A A}$ & $55 \pm 1$ & $0.18 \pm 0.01$ & - \\
UCNPs $^{\top \mathrm{m}} @ \mathrm{AP}$ & $20.09 \pm 0.09$ & $0.19 \pm 0.01$ & - \\
\hline
\end{tabular}


A
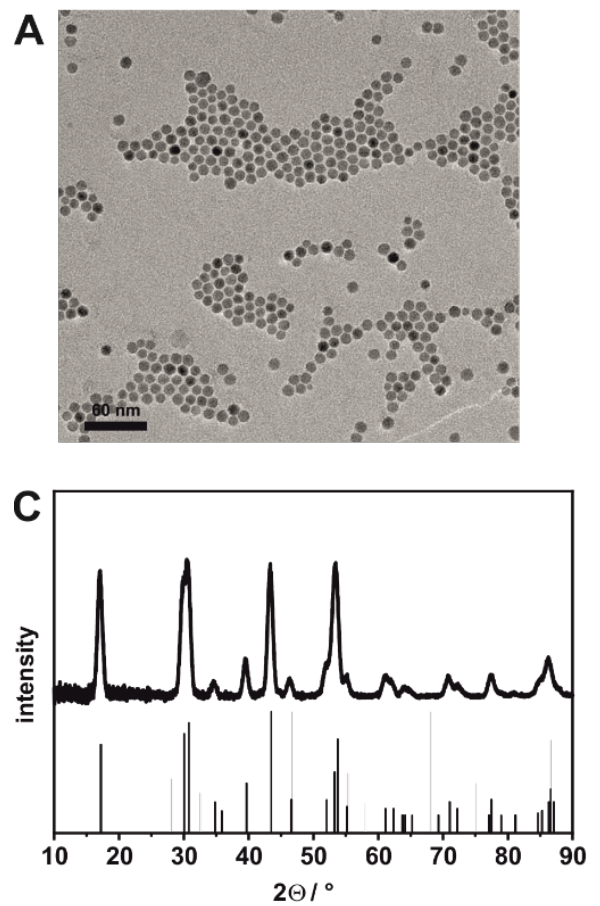
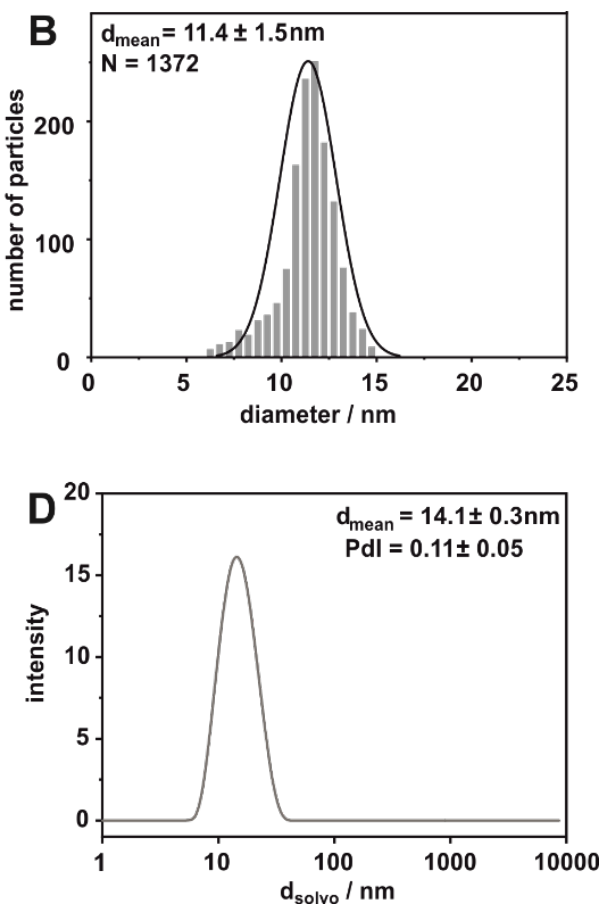

Figure S3. TEM images and corresponding particle size distributions of oleate coated $11.4 \pm 1.5 \mathrm{~nm}$ (on $8.8 \pm 0.9 \mathrm{~nm}$ particles) core-shell particles $\mathrm{NaYF}_{4}(24 \% \mathrm{Yb}, 0.5 \% \mathrm{Tm}) @ \mathrm{NaYF}_{4}$. X-ray powder diffraction pattern of these particles with standard pattern of hexagonal (black, ICDD PDF \#16-0334) and cubic (grey, ICDD PDF \#390724) phase NaYF.
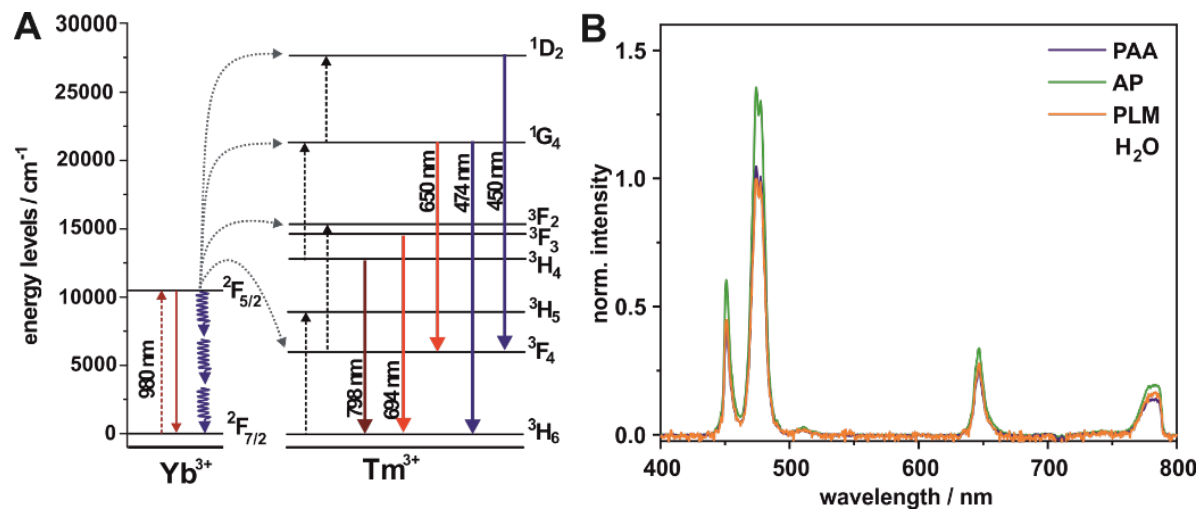

Figure S4. (A) Energy level diagram of UCNPs consisting of the activator/sensitizer pair $\mathrm{Yb}^{3+} / \mathrm{Tm}^{3+}$. (B) Luminescence spectra of AP, PLM and PAA coated $11.4 \mathrm{~nm} \mathrm{UCNPs} \mathrm{NaYF}_{4}(\mathrm{Yb}, \mathrm{Tm}) @ \mathrm{NaYF}_{4}$ in upon irradiation with $980 \mathrm{~nm}$ at $\sim 85 \mathrm{~W} \cdot \mathrm{cm}^{-2}\left(1 \mathrm{mg} \cdot \mathrm{mL}^{-1}\right.$, normalized to NucNPs). 
Table S3. Concentration of various ions in human plasma, phosphate buffers (PBS pH 7.4, 10x PBS pH 7.4, DBPS $\mathrm{pH}$ 7.2), common cell media (DMEM, L15, MEM, RPMI1460 from Thermofisher) and chosen concentrations with ionic strength (I) for the stability test.

\begin{tabular}{|c|c|c|c|c|c|}
\hline & \multirow{2}{*}{$\begin{array}{l}\text { human } \\
\text { plasma }\end{array}$} & \multirow{2}{*}{$\begin{array}{l}\text { phosphate } \\
\text { buffers }^{[10-12]}\end{array}$} & \multirow[t]{2}{*}{ media $^{[13-16]}$} & \multicolumn{2}{|c|}{ measurement conditions } \\
\hline & & & & $\mathrm{c} / \mathrm{mM}$ & $\mathrm{I} / \mathrm{mM}$ \\
\hline$\left[\mathrm{KH}_{2} \mathrm{PO}_{4}\right] / \mathrm{mM}$ & - & $1.1-2.0$ & $0-0.44$ & 0.44 & - \\
\hline$\left[\mathrm{Na}_{2} \mathrm{HPO}_{4}\right] / \mathrm{mM}$ & - & $3.0-8.1$ & $0.9-5.6$ & 1.34 & - \\
\hline total $\left[\mathrm{PO}_{4}{ }^{3-}\right] /$ & $1.0-1.5$ & 4.1-10.0 & $0.9-5.6$ & 1.78 & 3.6 \\
\hline $\mathrm{mM}$ & & & & 8.9 & 17.8 \\
\hline$\left[\mathrm{NaHCO}_{3}\right] / \mathrm{mM}$ & $23-28$ & - & $23.8-44.0$ & & - \\
\hline total $\left[\mathrm{CO}_{2}\right] / \mathrm{mM}$ & $23-28$ & - & $23.8-44.0$ & 44.0 & - \\
\hline [acetate] / mM & - & - & - & 10 & - \\
\hline$\left[\mathrm{Na}_{2} \mathrm{SO}_{4}\right] / \mathrm{mM}$ & - & - & - & 0.8 & 2.4 \\
\hline$\left[\mathrm{SO}_{4}{ }^{2-}\right] / \mathrm{mM}$ & 0.5 & - & $0.4-0.8$ & - & - \\
\hline$\left[\mathrm{CaCl}_{2}\right] / \mathrm{mM}$ & - & $0-0.9$ & $0-1.8$ & 1.8 & 5.4 \\
\hline$\left[\mathrm{Ca}^{2+}\right] / \mathrm{mM}$ & $2.2-2.6$ & - & - & - & - \\
\hline$\left[\mathrm{MgCl}_{2}\right] / \mathrm{mM}$ & - & $0-0.5$ & $0-1.0$ & 1.0 & 3 \\
\hline$\left[\mathrm{Mg}^{2+}\right] / \mathrm{mM}$ & $0.6-1.0$ & - & - & - & - \\
\hline$[\mathrm{NaCl}] / \mathrm{mM}$ & - & 137.9- & $103-137.9$ & 137.9 & 137.9 \\
\hline & & 155.2 & & & \\
\hline$\left[\mathrm{Na}^{+}\right] / \mathrm{mM}$ & $136-$ & - & - & - & - \\
\hline & 145 & & & & \\
\hline$[\mathrm{KCl}] / \mathrm{mM}$ & - & 0.2 .7 & 5.3 & 5.3 & 5.3 \\
\hline$\left[\mathrm{K}^{+}\right] / \mathrm{mM}$ & $3.5-5$ & - & - & - & - \\
\hline total I (w/o CO & & & & & 157.6 \\
\hline acetate) / mM & & & & & \\
\hline
\end{tabular}




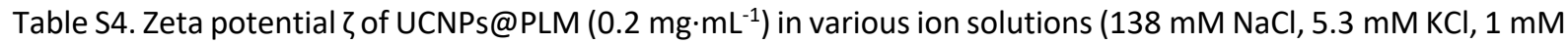
$\mathrm{MgCl}_{2}, 1.8 \mathrm{mM} \mathrm{CaCl}_{2}, 0.8 \mathrm{mM} \mathrm{Na}_{2} \mathrm{SO}_{4}$ ) and at different $\mathrm{pH}$ values (1.8 mM phosphate at $\mathrm{pH}$ 7.4, $44 \mathrm{mM}$ carbonate at $\mathrm{pH}$ 9.2) at physiological concentrations and in acetate buffer $(10 \mathrm{mM}$ at pH 4).

\begin{tabular}{ccc}
\hline & $\zeta_{0 \mathrm{~h}} / \mathrm{mV}$ & $\zeta_{96 \mathrm{~h}} / \mathrm{mV}$ \\
\hline $\mathbf{1 3 8} \mathrm{mM} \mathrm{NaCl}$ & $-36 \pm 3$ & $-33 \pm 3$ \\
$\mathbf{5 . 3} \mathrm{mM} \mathrm{KCl}$ & $-56 \pm 3$ & $-55 \pm 1$ \\
$\mathbf{1 . 8} \mathrm{mM} \mathrm{CaCl}_{2}$ & $-16.4 \pm 0.6$ & $-20 \pm 1$ \\
$\mathbf{1 ~ \mathrm { mM } \mathrm { MgCl } _ { 2 }}$ & $-16.1 \pm 0.8$ & $-17 \pm 1$ \\
$\mathbf{0 . 8} \mathrm{mM} \mathrm{Na}_{2} \mathrm{SO}_{4}$ & $-50 \pm 1$ & $-49.8 \pm 0.9$ \\
$\mathbf{1 0 ~} \mathrm{mM}_{4}$ acetate, pH 4 & $-40 \pm 4$ & $-38 \pm 1$ \\
$\mathbf{1 . 8} \mathrm{mM}$ phosphate, pH 7.4 & $-52 \pm 3$ & $-50 \pm 2$ \\
$\mathbf{4 4 ~ m M ~ c a r b o n a t e , ~ p H ~ 9 . 2 ~}$ & $-54 \pm 7$ & $-57 \pm 6$
\end{tabular}
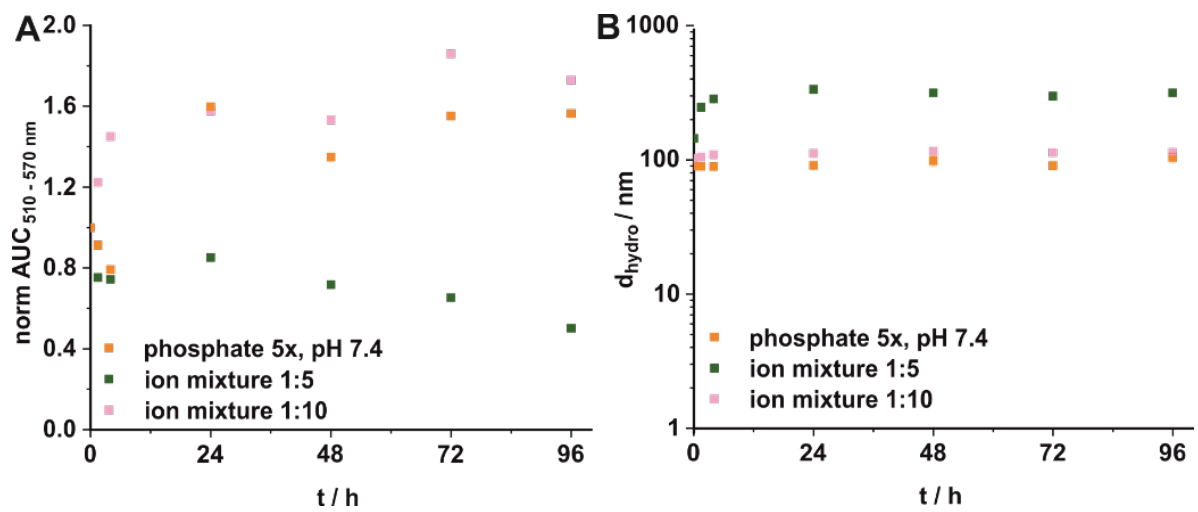

Figure S5. Influence of ion mixtures diluted 1:5 and 1:10 of physiological concentration $(27.6 / 13.8 \mathrm{mM} \mathrm{NaCl}$, 1.06/0.53 mM KCl, 0.2/0.1 mM MgCl$, 0.36 / 0.18 \mathrm{mM} \mathrm{CaCl}_{2}, 0.16 / 0.08 \mathrm{mM} \mathrm{Na}_{2} \mathrm{SO}_{4}$ ) and 5 times concentrated phosphate $(8.9 \mathrm{mM})$ at $\mathrm{pH} 7.4$ on the stability of the particles UCNPs@PLM $\left(0.2 \mathrm{mg} \cdot \mathrm{mL}^{-1}\right)$ measured by the area under the green curve $(510-570 \mathrm{~nm})$ upon irradiation with $980 \mathrm{~nm}\left(\mathrm{cw}, 85 \mathrm{~W} \cdot \mathrm{cm}^{-2}\right.$, normalized to NucNPs $)$ and the hydrodynamic diameter for $96 \mathrm{~h}$. 

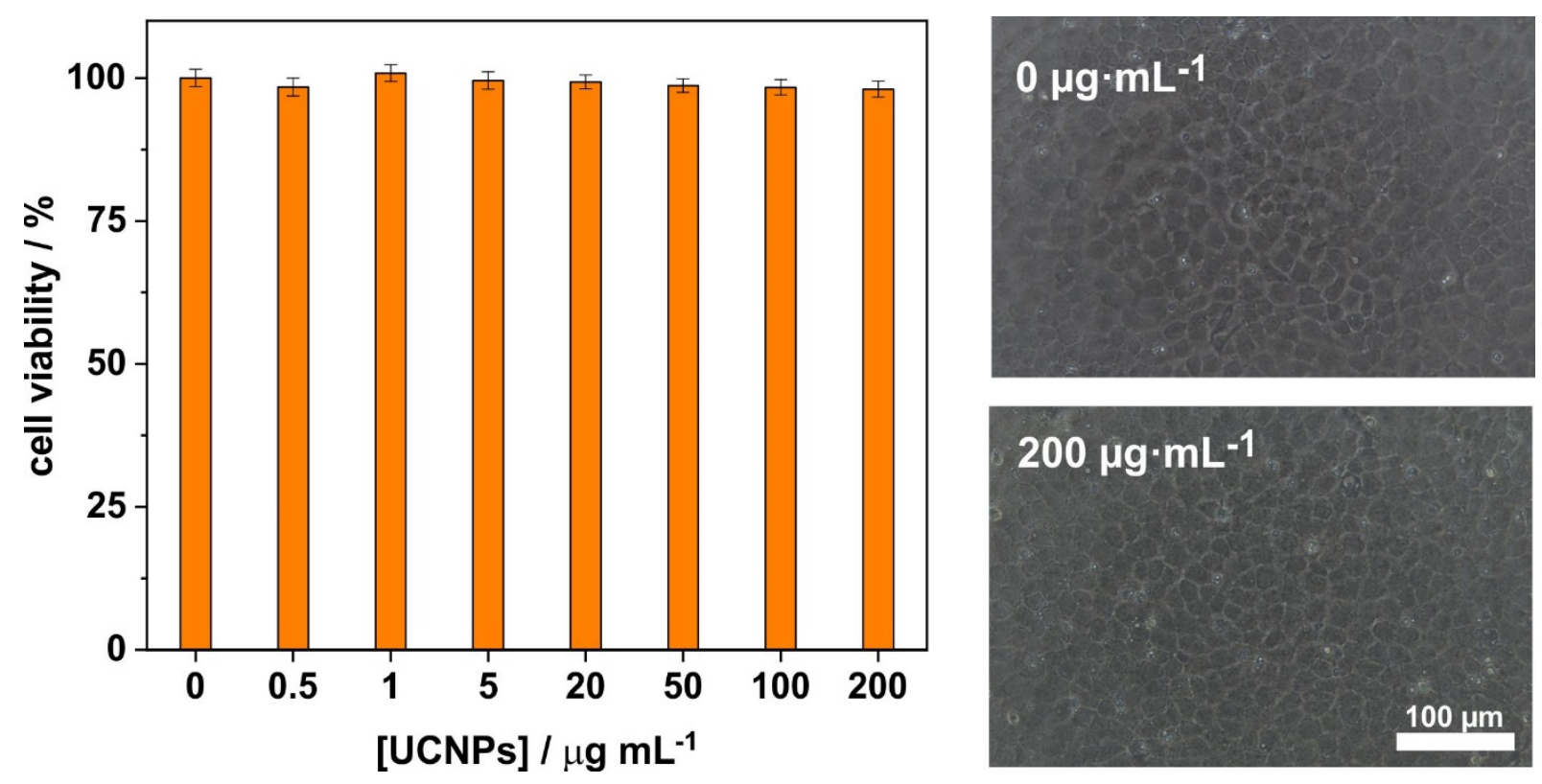

Figure S6. PrestoBlue ${ }^{\mathrm{TM}}$ assay to determine the cell viability of normal rat kidney (NRK) cells upon treatment with UCNPs@PLM in medium Leibovitz L15 + FCS (5\%) + penicillin/streptomycin $\left(100 \mu \mathrm{g} \cdot \mathrm{mL}^{-1}\right)$ in various concentrations $\left(0.5-200 \mu \mathrm{g} \cdot \mathrm{mL}^{-1}\right)$ for $24 \mathrm{~h}(\mathrm{~N}=3)$ and corresponding light microscopic images of untreated and treated $\left(200 \mu \mathrm{g} \cdot \mathrm{mL}^{-1}\right) \mathrm{NRK}$ cells after $24 \mathrm{~h}$ to prove that the cell layer is still intact. 


\section{References}

[1] Tan, M. C.; Al-Baroudi, L.; Riman, R. E. Surfactant Effects on Efficiency Enhancement of Infrared-to-Visible Upconversion Emissions of $\mathrm{NaYF}_{4}: \mathrm{Yb}-\mathrm{Er}$. ACS Appl. Mater. Interfaces 2011, 3, 3910-3915.

[2] Tong, L.; Lu, E.; Pichaandi, J.; Nitz, M.; Winnik, M. A. Quantification of Surface Ligands on NaYF 4 Nanoparticles by Three Independent Analytical Techniques. Chem. Mater. 2015, 27, 48994910.

[3] Zhang, L.; He, R.; Gu, H.-C. Oleic acid coating on the monodisperse magnetite nanoparticles. Appl. Surf. Sci. 2006, 253, 2611-2617.

[4] Rinkel, T.; Nordmann, J.; Raj, A. N.; Haase, M. Ostwald-ripening and particle size focussing of sub-10 $\mathrm{nm} \mathrm{NaYF}_{4}$ upconversion nanocrystals. Nanoscale 2014, 6, 14523-14530.

[5] Dong, A.; Ye, X.; Chen, J.; Kang, Y.; Gordon, T.; Kikkawa, J. M.; Murray, C. B. A generalized ligandexchange strategy enabling sequential surface functionalization of colloidal nanocrystals. $J$. Am. Chem. Soc. 2011, 133, 998-1006.

[6] Lin, C.-A. J.; Sperling, R. A.; Li, J. K.; Yang, T.-Y.; Li, P.-Y.; Zanella, M.; Chang, W. H.; Parak, W. J. Design of an amphiphilic polymer for nanoparticle coating and functionalization. Small 2008, 4, 334-341.

[7] Demnati, I.; Grossin, D.; Combes, C.; Parco, M.; Braceras, I.; Rey, C. Biomed. Mat. 2012, 7, 54101.

[8] Padilla, O. "Blood Tests: Normal Values", can be found under https://www.merckmanuals.com/professional/resources/normal-laboratory-values/bloodtests-normal-values\#v8508814, 2018.

[9] McKee, T. J; Komarova, S. V. Is it time to reinvent basic cell culture medium? Am. J. Physiol. Cell Physiol. 2017, 312, C624-C626.

[10] "Invitrogen ${ }^{\mathrm{TM}}$ : PBS (10X) pH 7.4", can be found under https://www.thermofisher.com/order/catalog/product/AM9624\#/AM9624.

[11] "Technical Resources - Media Formulations: 10010 - PBS, pH 7.4", can be found under https://www.thermofisher.com/de/de/home/technical-resources/mediaformulation.160.html.

[12] "Technical Resources - Media Formulations: 14040 - DPBS, calcium, magnesium", can be found under https://www.thermofisher.com/de/de/home/technical-resources/mediaformulation.144.html.

[13] "Technical Resources - Media Formulations: 61870 - RPMI 1640, GlutaMAX(TM)", can be found under https://www.thermofisher.com/de/de/home/technical-resources/mediaformulation.122.html.

[14] "Technical Resources - Media Formulations: 31095 - MEM", can be found under https://www.thermofisher.com/de/de/home/technical-resources/mediaformulation.196.html.

[15] "Gibco' ${ }^{\text {TM }}$ Leibovitz's L-15 Medium", can be found under https://www.thermofisher.com/order/catalog/product/11415064?SID=srch-srp-.

[16] "Gibco ${ }^{\mathrm{TM}}$ : DMEM, High Glucose", can be found under https://www.thermofisher.com/order/catalog/product/11965092?SID=srch-srp11965092\#/11965092?SID=srch-srp-11965092. 